https://doi.org/10.22364/ruslat.9.12

\title{
Сергей Доценко
}

\section{О литературном генезисе имени героя книги А. Ремизова «Учитель музыки»}

В статье рассматривается автобиографический и митературный генезис имени «Корнетов», главного героя книги А. Ремизова «Учитель музыки. Каторжная идилмия». Автор приходит к выводу, что имя «Корнетов» является рефлексом Аетской мечты Ремизова стать кавалергардом. ОАновременно образ кавалергарда становится элементом китературной парадигмы «кавалергарА - учитель - разбойник».

Кмючевые слова: русская митература, прототип, митературный герой, генезис, А. Ремизов, А. Блок.

С первой страницы, с первой строки мюбой из ремизовских книг чувствуется, что это, как говорится, настоящее. Но как оно Аиковинно, это «настоящее», и сколько мыслей возбужАает оно, независимо от непосреАственного содержания текста, сколько мыслей о нашей митературе вообще, о ее возможном будущем, о ее прошиом ...

Г. ААамович

ГАавный герой автобиографической книги Ремизова «Учитель музыки» (1934-1949) - Александр Александрович Корнетов. О генезисе этого имени (Корнетов) пишет сам автор в гл. «Чинг-Чанг»:

«Прошу не путать никого с Александром Александровичем Корнетовым, ни из его знакомых и приятелей, это я сам. Имя Корнетову Аано было еще в Петербурге в честь Александра Александровича Блока, а фамилия «Корнетов» не столько инструментальная по профессии учителя музыки, сколько кавалерийская: заветная мечта Александра Александровича, которую он неоднократно высказывац, - “быть бы мне михим корнетом, ездить на коне, как у Толстого в «Войне и мире», выделывать всякие ухарские штуки!” - фамилия Корнетов Аана по контрасту с его небоевым образом жизни» $[9: 437]^{1}$.

1 В примечаниях к «Учителю музыки» сообщается: «Изначально образ Корнетова имеет полигенетический характер. Среди его более прямых реальных прототипов сам автор, в детстве учившийся играть на корнет-а-пистоне $<\ldots .>$ [9: 473]. Аобавим, что этот музыкальный Ауховой инструмент косвенно тоже отсылает к «военной» теме: корнет-а-пистон (франц. cornet a pistons - букв. рожок с клапанами) 
Эта ссылка на мечту Блока быть «лихим корнетом» напоминает анекАоты-апокрифы о великих писателях. ОАнако в воспоминаниях о Блоке Аействительно можно найти упоминания о его увлечении верховой езАой.

«Он рано выучияся ездить верхом, красиво сидел на мошади и мовко и смело ездим. При всей своей мюбви к мошадям он умел их заставцять себя слушаться. $<\ldots>$ Саша уезжал верхом иногда на целые Ани и в этих поездках исколесил все окрестности Шахматова на Аалекое пространство» $[2: 60]^{2}$.

Но в действительности речь идет скорей не о мечте Блока, а о мечте самого Ремизова. Вспомним его письмо А. Н. Чеботаревской от 23.05.1907 г., в котором Ремизов (на просьбу сообщить о себе биографические сведения) несколько шутливо отвечал:

«Хотел быть кавалергардом, разбойником и учителем чистописания» [цит. по: 3: 447].

А в мемуарной книге «Подстриженными глазами», в которой описаны Аетские и отроческие годы жизни писателя, есть такое признание Ремизова:

$\ll<\ldots>$ Мне самому хотелось быть серебряным всадником - таким вот блестящим великаном на коне! И долго потом меня не оставмяла эта мечта, и когАа меня спрашивали, кем я хочу быть, я неизменно отвечал: “кавалергардом" » [7:143].

Более чем очевидно, что мечта «стать кавалеристом» (кавалергарАом), - это мечта скорей не Блока, а самого Ремизова ${ }^{3}$ В 1910 г. эта мечта

применялся в военном оркестре, а его разновидность корнет рожок (signalhorn, cor de signal) - в качестве военного рожка Аля подачи сигналов.

2 Мемуары М. А. Бекетовой «Александр Блок и его мать» были опубликованы в 1925 г. (сМ.: Бекетова 1925), и можно преАполагать, что именно они стали источником ремизовкого апокрифа о мечте А. Блока стать кавалеристом.

3 В той же книге «ПоАстриженными глазами» Ремизов вспоминает, что отец его в шутку «и меня и моего брата $<\ldots>$ называц за нашу мелкорослость "гвардейцами" $<\ldots>\gg[7: 142]$. Впрочем, в мемуарной книге «Иверень» этот список более Алинный и более разнообразный: «Мечтал саелаться певцом, музыкантом, актером, художником, учителем чистописания, парикмахером, пиротехником (пускать потешные огни и волшебные звезды), философом и ученым - и попал в митературу» [7:270]. Отметим, что само понятие кавалергарА может выступать и, скорее всего, выступает как эмблема Аворянского, т. е. «благородного», мира. Кавалергарды (от франц. cavalier - всадник и garde - охрана) - особая кавалерийская часть в русской гвардии в XVIII-начаме XX вв. Кавалергарды исполняли обязанности телохранителей и почётной стражи во время коронаций и Аругих торжеств. Впервые сформирована в 1724 г. на время коронации Екатерины I из офицеров гвардии. Позже (в 1725-1731 гг. и 1762-1796 гг.) существовали поА названием КавалергарАского корпуса. В 1797 г. быми расформированы, но в 1799 г. восстановлены как гвардия императора Павла I. В 1800 г. преобразованы в гвардейский кавалерийский полк [5]. Этимологически в самом слове «кавалергарА» акцентировано значение: «Аворянин», «рыцарь». В качестве примечательного факта отметим, что своего 
появмяется в размышиениях главного героя повести А. Ремизова «Крестовые сестры» (1910):

«КогАа в Аетстве хотем Маракулин быть к а в а $\Lambda$ е р г а р А о м, он молился, чтобы Господь сАелал так, помог ему сАелаться кавалергардом, а когАа хотел быть р а 3 о й н и к о м, то в тех же словах молился, Аишь с заменою кавалергарда разбойником, и так же точно

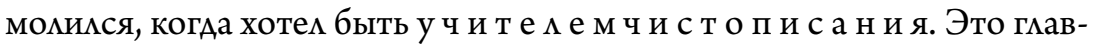
ные были его молитвы о самом себе еще в Москве, в Таганке <...> > [8: 137; везде разрядка А. Ремизова. - С. А.].

Такое сочетание в ремизовском сознании образов «кавалергарда», «учителя чистописания» и «разбойника» выгляАит параАоксальным. Но можно преАположить, что это не случайность, а осознанная игра известными китературными и культурными типами.

ПрежАе всего, все три образа Аают своеобразную, но тем не менее логичную социокультурную парадигму. КавалергарА - образ, занимающий высокое и престижное место в социальной иерархии ${ }^{4}$. Разбойник - образ, подразумевающий «положение выключенности из основной социальной иерархии» [6: 116], т. е. выступает как контрастный относительно образа кавалергарда ${ }^{5}$. А образ учителя чистописания в этой социальной парадигме занимает промежуточную позицию, т. к. подразумевает вкмюченность в со-

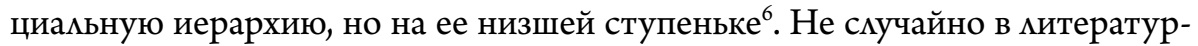
ном сознании образ камлиграфа (а учитель чистописания - это именно и прежде всего калмиграф), «переписчика» устойчиво ассоциируется с беАным петербургским чиновником (например, гоголевским Башмачкиным). В этой связи знаменательно увлечение Маракулина камлиграфией - искусством переписчика, что явно проецирует ремизовского героя на героя гоголевской «Шинеми». Как считает В. Н. Топоров, сама фамилия героя (Маракулин) имеет среди прочего «писарскую» мотивировку [11: 146, 156].

Корнетова Ремизов «поселим» в Петербурге на Кавалергардской ул. [9: 10]. Прототипом же этого аАреса была квартира, в которой А. Ремизов жил в Петербурге с августа 1906 г. по июнь 1907 г. (КавамергарАская ум., А. 8, кв. 28).

4 Степень высоты подчеркнута невозможностью ее достичь: ни Маракулин, ни его прототип А. М. Ремизов, сын купца 2-й гильдии, стать кавалергардом не мог в принципе (по причине своего сословного происхожАения).

5 Более подробно об образе разбойника в творчестве А. Ремизова см.[4: 144-159].

6 Но парадокс закмючается в том, что корнет - первый обер-офицерский чин в кавалерии (до 1917 г.); введен в 1731 г. взамен звания прапорщика и первоначально относиися к XIV классу Табели о рангах. Отменен в 1765 г. и восстановлен Павлом I в 1798 г. В результате реформы 1884 г. чин корнета был переведен в XII класс. В то время как переписчик Акакий Башмачкин имеет чин титулярного советника, который относился к IX классу Табели о рангах (и соответствовац чину армейского штабс-капитана). Впрочем, эта оппозиция «высокий» - «низкий» уже нейтрализуется в образе Аругого камлиграфа - князя Мышкина, в котором уживаются одновременно благородное Аворянское происхождение и низкое занятие. 
Причем характерно, что камииграфическое искусство Маракулина, как и Башмачкина, не имеет никакой практической помьзы:

«К празАнику Аиректору подается отчет, отчет обыкновенно пишется на машине - самый обыкновенный отчет, а вот ему <Маракумину. - С. А.> почему-то непременно захочется самому переписать и своею рукою $<\ldots>$ и ночи и Ани он упорно выводит букву за буквой, строчит ровно, точно бисером нижет, и не раз перепишет, пока не Аобьется такого отчета, хоть на выставку неси, вот Ааже какого! - почерком Маракулин славился. Завтра же этот отчет заложат куда-нибудь в бумаги, особого внимания никто не обратит, никому он такой не нужен, а времени и труда затрачено много и без толку» [8: 15-16].

Русская митературная традиция знает образ, одновременно соединяющий все три упомянутые ипостаси. Это - пушкинский Аубровский, который выступает и как гвардейский офицер (он - корнет оАного из гварАейских полков $)^{7}$, и как разбойник (в романтической его версии), и как учитель-француз.

Трудно сказать, в какой мере Ремизов осознавац эту митературную анамогию. По крайней мере, Аве роли (корнета и «учителя чистописания») примеряет на себя Аругой его герой, в еще большей степени автобиографический - Александр Александрович Корнетов, главный герой рассказов «ГАаголица» (1912), «Оказион» (1913) и мемуарной книги «Учитель музыки», которую сам писатель определил в предисловии: «"Учитель музыки” - моя бытовая автобиография» [9: 4].

Корнетов носит многозначительную «офицерскую» фамилию и так же, как и Маракулин, вмадеет камииграфическим искусством:

«Не “ученый”, нет у Корнетова ни ученых трудов, ни орленого золотого значка Археологического Института, но и без всяких отличий, как мовко, как бережно, затейливо выводит он крючки и ставит крестики, впору тому же ученому и книжному справщику» [9: 8].

Что касается мотива разбойника, то в «Учителе музыки» он сохранился мишь в названии главы «Воровской самоучитель»: так Корнетов называет тетрадь, в которую «записывает он не какие-либо выдающиеся события общественной жизни, регистрируемые газетами, а всякую мемочь из нашей “живой” подъяремной жизни» [9: 286]. И в еще более реАуцированном виде - в подзаголовке всей книги: «Каторжная иАимлия».

7 СМ.: «ВАадимир Аубровский воспитывался в Кадетском корпусе и выпущен был корнетом в гвардию $\langle\ldots>\gg[10: 154]$. 


\section{Литература}

1. М. А. Бекетова, Александр Блок и его мать: Воспоминания и заметки. А.; М., 1925.

2. М. А. Бекетова, «АлексанАр Блок и его мать», АлексанАр Блок в воспоминаниях современников. М., 1980. Т. 1. С. 39-69.

3. А. Грачева, «Революционер А. Ремизов: Миф и реальность», Аица: Биографический альманах. 3. СПб., 1993. С. 419-437.

4. С. Н. Аоценко, «Почему Маракулин хотел стать разбойником: (Из комментария к повести А. Ремизова “Крестовые сестры” », Блоковский сборник XIV. Tartu, 1998. С. $144-159$.

5. «История кавалергардов 1851», История кавалергардов и Кавалергардского Ее Величества полка с 1724 по 1-е июля 1851 года История кавалергардов и КавалергарАского её величества полка с 1724 по 1 июля 1851 года. СПб., 1851.

6. Ю. Мотман, Б. Успенский Б. «“Изгой” и “изгойничество” как социальнопсихологическая позиция в русской культуре преимущественно Аопетровского периода: (“Свое” и “чужое” в истории русской культуры)», Учен. зап. Тарт. гос. ун-та. 1982. Вып. 576. С. 110-121.

7. А. Ремизов, Собрание сочинений. Т. 8. Подстриженными глазами. Иверень. М.: Русская книга, 2000.

8. А. Ремизов, Собрание сочинений. Т. 4. Пцачужная канава. М.: Русская книга, 2001.

9. А. Ремизов, Собрание сочинений. Т. 9. Учитель музыки: Каторжная идимлия. М.: Русская книга, 2002.

10. А. С. Пушкин, Полное собрание сочинений: В 10 т. $\Lambda .:$ Наука, 1978. Т. 6.

11. В. Топоров, «О “Крестовых сестрах” А. М. Ремизова: Поэзия и правда (Статья первая)», Учен. зап. Тарт. гос. ун-та. 1989. Вып. 857. С. 138-158.

\section{Alekseja Remizova grāmatas "Mūzikas skolotājs" personāža vārda literārā ǵenēze}

Rakstā aplūkota Alekseja Remizova grāmatas "Mūzikas skolotājs. Katorgas idille” galvenā varoṇa Korņetova vārda autobiogrāfiskā un literārā genēze. Autors secina, ka vārds Korņetovs ir Remizova bērnības sapņu refleksija, jo rakstnieks ir vēlējies kḷūt par kavalergardu. Vienlaikus kavalergarda tēls kḷūst par literārās paradigmas kavalergards skolotājs - laupìtājs elementu.

\section{Literary Genesis of the Name of the Character of A. Remizov`s "The Music Teacher"}

The article deals with the autobiographical and literary genesis of the name of "Kornetov", the main character of A. Remizov's book "The Music Teacher. Prison idyll". The author concludes that the name "Kornetov" is a reflection of Remizov's childhood dream of becoming a Chevalier Guard. At the same time, the image of the Chevalier Guard becomes an element of the literary paradigm "Chevalier Guard - teacher - robber". 